\title{
Prevention of Accounting Fraud in the Village Government
}

\author{
Fila Sartika Sari*, Ari Kamayanti \\ Accounting Department \\ State Polytechnic of Malang \\ Malang, Indonesia \\ *filasartika1405@gmail.com, kamayanti.ari@gmail.com
}

\begin{abstract}
This research has a purpose to examine factors that affect the level of accounting fraud. The population of this research was employees who work in 10 villages in Kesamben District, Blitar Regency. The approach used in this research was a mixed method, in which a qualitative approach was used to strengthen quantitative findings. The data were taken by directly spreading questionnaires to the respondents and there were 40 questionnaires and also the answers from the interview with the village head of Kemirigede. The data analysis used SmartPLS 3.0. The result of this research shows that individual morality positively affects accounting fraud. Besides that the result of this research shows that the information asymmetry, effectiveness of internal control, and conformity of compensation not significant towards accounting fraud. The result if the interview also supports these findings.
\end{abstract}

Keywords-information asymmetry, effectiveness of internal control, conformity of compensation, level of accounting fraud, individual morality

\section{INTRODUCTION}

The presentation of financial reports to public sector organizations should be carried out fairly and transparently because these reports are a means of communication and can also be considered as a form of responsibility for the performance of government organizations to the public. The tendency of accounting fraud is now increasingly prevalent in Indonesia in various sectors, not only the private sector but also the public sector. According to the Indonesia Corruption Watch (ICW), there were 158 village officials accused of corruption cases in 2018. After the ratification of Law No.6 of 2014 concerning Village Funds, each village received APBD of up to IDR 1 billion from the Central Government so that the village development process could be carried out by both followed by the obligation to make budget reports in each village. This budget reporting is the control exercised by the central government to the village government to avoid fraud in the management of village funds.

This research used GONE theory and auditing theory. The GONE theory is a theory that is often used in fraud research. GONE stands for four indicators that encourage someone to commit fraud, which consists of Greed, Opportunity, Need, and
Exposure. Normative theory and descriptive theory are classifications of auditing theories based on their nature. Normative theory is a theory that should be implemented in the implementation of auditing. Meanwhile, the descriptive theory is a theory that is actually implemented at the time of auditing. There are four basic concepts in auditing theory [1] which include evidence, fair presentation, independence, and ethica conduct.

According to the Indonesian Institute of Accountants (IAI) accounting fraud is an act of misuse or embezzlement that should not have been carried out. According to the Indonesian Institute of Accountants (IAI) accounting fraud is an act of misuse or embezzlement that should not have been carried out. The Association of Certified Fraud Examiners (ACFE 2014) classifies accounting fraud into three types which include financial statement fraud, asset misappropriation, and corruption.

The moral quality of a person is a matter of loyalty to one's own heart. Morality is the implementation of the obligations of a human being who respects the applicable law, while the law itself is written in the human heart [2]. Kohlberg's theory in Boli [3] argues that moral reasoning is the basis of ethical behavior. Moral reasoning and categorized into six stages consisting of obedience and punishment orientation, hedonistic-instrumental orientation, good individual orientation, order and authority orientation, and conscience orientation. The six stages are then divided into three levels, namely the pre-conventional level, the conventional level, and the post-conventional level.

Information asymmetry is a situation where there is an imbalance of information between internal and external parties. With this imbalance of information, it will create opportunities that can be used by internal parties to commit fraud [4]. Information asymmetry in Dewi [2] is classified into two types, namely vertical information asymmetry and horizontal information asymmetry.

Government Regulation No. 60 of 2008 concerning the Government Internal Control System explains that the internal control system is an integral process of actions and activities carried out periodically by the leadership and all employees to 
achieve organizational goals through effective and efficient activities, reliability of financial reporting, asset security state, and compliance with laws and regulations. Setiawan et al [5] and Damayanti [6] show that the effectiveness of internal control has a negative effect on the tendency of accounting fraud. The better the effectiveness of an agency's internal control, the lower the tendency to commit accounting fraud.

According to Hasibuan [7] compensation is all income in the form of money, direct or indirect goods received by employees as compensation for services provided to the company. Shintadevi and Amalia [8] show that the suitability of compensation has a negative effect on the tendency of accounting fraud. If the suitability of providing compensation for work is higher, then the tendency for accounting fraud to decline.

\section{METHODS}

\section{A. Data Collection Method}

Sources of data used for this study are primary data sources including questionnaires and interviews. Distributed questionnaires and interview questions are replicas of previous studies modified according to the needs of researchers. In this study, the independent variables used are individual morality, information asymmetry, effectiveness of internal control, and suitability of compensation and the dependent variable in this study is the tendency of accounting fraud. The instrument used to measure individual morality refers to the research of Nugroho [9], information asymmetry refers to Amalia's research [8] which is added by the researcher for monitoring indicators and auditor examination, internal control refers to Arifah's research [10], the suitability of compensation refers to Amalia's research [8], as well as the tendency of accounting fraud to refer to Fauzya's research [11]. The measurement scale used is a Likert scale with a weight of 1-5. The questionnaire is a closed type which has some choice to answer the question for respondents. This research does use the literature of the same research which has been conducted. So could be gotten the related theory to support this research as the reference material and consideration. The method used in this research is mix methods with a sequential explanatory strategy. In this study, using the between-methods triangulation, which is a method that uses qualitative and quantitative instruments.

\section{B. Data Analysis}

The stages carried out in this research for data collection and analysis include compiling a research plan, managing permits, collecting quantitative data, analyzing quantitative data, collecting qualitative data, and drawing conclusions based on the data that has been collected and analyzed.

The data analysis technique used in this study for quantitative data is multiple linear regression analysis techniques to test the effect of each independent variable on the dependent variable using SmartPLS version 3.0 software. The analysis carried out includes analysis of the measurement model (outer model), structural model analysis (inner model), and hypothesis testing. Researchers conducted exploratory indepth interviews to further the understanding of the situation at the village offices in Kesamben District, Blitar Regency to clarify the results obtained from the analysis of quantitative data statistical results. Researchers made research conclusions based on quantitative data analysis and qualitative data accompanied by survey results.

\section{RESULTS AND DISCUSSION}

The questionnaires were distributed directly to 40 village officials in Kesamben District in 2020. Of the 40 questionnaires distributed, the return rate was $95 \%$, which amounted to 38 questionnaires. The assistive instrument in this study was the result of an interview with Mr. Hari Purnawan as the head of the village from the best village which was recommended directly by Mr. Ir. Setiyana, MM as the Head of Kesamben Sub-district.

This research data has already passed the outer model testing and inner model testing. Then could be conducted the hypothesis testing to define the effect of all factors on the level of accounting fraud, namely due individual morality, information asymmetry, the effectiveness of internal control, and conformity of compensation. The result of hypothesis testing analysis could be seen as the table 1 below:

TABLE I. HYPOTHESIS TESTING RESULTS

\begin{tabular}{|l|l|l|l|l|l|l|}
\hline Variable & $\begin{array}{l}\text { Original } \\
\text { pample (O) }\end{array}$ & $\begin{array}{c}\text { ample Mean } \\
(\mathbf{M})\end{array}$ & $\begin{array}{l}\text { Standard } \\
\text { Deviation } \\
\text { (STDEV) }\end{array}$ & $\begin{array}{l}\text { T Statistic } \\
\text { O?STDEV }\end{array}$ & P Values & Expln. \\
\hline $\mathrm{X} 1$-> Y & 0.983 & 0.967 & 0.074 & 13.218 & 0.000 & Rejected \\
\hline $\mathrm{X} 2$-> Y & 0.044 & 0.058 & 0.079 & 0.556 & 0.289 & Rejected \\
\hline $\mathrm{X} 3$-> Y & 0.098 & -0.075 & 0.072 & 1.368 & 0.086 & Rejected \\
\hline $\mathrm{X} 4$-> Y & 0.046 & 0.027 & 0.041 & 1.111 & 0.134 & Rejected \\
\hline
\end{tabular}

The model can be interpreted as follows:

- The results in the individual morality variable show a tstatistic value of 13,218, a p-value of 0,000 , and an original sample of 0.983 . P-values and t-statistic values that are show the numbers 0.000 and 13,218, where these numbers actually meet the criteria to state that the hypothesis is acceptable. However, if you look at the original sample value that is owned, which is the number 0.983 , this means that the predictive nature of the individual morality variable on the tendency of accounting fraud is positive which is the opposite of the hypothesis. So based on the test results above, it can be concluded that the first hypothesis is rejected. Regression coefficient of variable X2 (Integrity) obtained by 0,895 with positive coefficient direction. This shows that higher iintegrity can improve audit quality in financial.

- The results of the information asymmetry variable showed a t-statistic value of 0.556 , a p-value of 0.289 , and the original sample value of 0.044 . So based on the test results above, it can be concluded that the second 
hypothesis is rejected. The results of the data analysis indicate that information asymmetry has no effect on the tendency of accounting fraud in the village government.

- The results of the internal control effectiveness variable show a t-statistic value of 1.368 , a p-value of 0.086 , and the original sample of -0.098 . So based on the test results above, it can be concluded that the third hypothesis is rejected.

- The result of the conformity of the compensation variable shows the t-statistic value of 1.111 , the $p$-value of 0.134 , and the original sample of 0.046 . So based on the test results above, it can be concluded that the fourth hypothesis is rejected. Statistical analysis shows that the suitability of compensation does not affect the tendency of accounting fraud in the village government.

\section{A. The Effect of Individual Morality on the Tendency of Accounting Fraud}

According to the opinion of the researcher, this can be caused by the respondent's understanding of morality in which a person is said to be moral when obeying a boss. This is supported by the assumption that a leader or boss is a figure who is highly respected and this situation has become a "culture" in the community. This research was conducted at the village government, where the assumption that a village head has a very exalted image or is considered a "king" has become a "culture" both by the village officials and the public. The culture called the "Power Distance" cultural environment. In accordance with the results of research by Hofstede, G. [12] which states that Indonesia has a "power distance" index of 78 which explains the very high power distance culture in Indonesia. In a cultural environment with a high power distance index, employees are more likely to be motivated to work by imitating the behavior of the leader and the fatherly nature of the leader who pays attention to employees. Based on the above, the results show that due to the high power distance cultural environment, many respondents are willing to follow orders from their boss without first considering whether the orders are negative or positive. Because respondents think that the moral act will provide benefits in supporting their careers. Whereas basically all village officials must obey the applicable rules, not the orders of their boss or leaders. This is also supported by the results of the research interviews. According to Mr. Hari Purnawan as the informant stated that the level of morality of a person is related to human resources. Therefore, the recruitment of new officials must pay attention to the level of education the village apparatus has. Other than that, special activities were also carried out to develop the individual morality of village officials. This is shown in the following interview results:

"So, for special activity there is an increase in the capacity of village officials. We always involve resource persons related to increasing the capacity of village officials to create more competent village officials. Resource persons usually come from the sub-district, Community and Village Empowerment Service, and the inspectorate. "

The village head of Kemirigede is very aware that a person's morality is very important both for carrying out work or in social life. Although many village officials in Kesamben District have an understanding that when someone obeying their superiors is considered a "moral" act, Mr. Hari Purnawan continues to make efforts so that the culture of seeing the village head as a "king" will gradually diminish. Among the efforts made were conducting training by presenting trusted sources to increase the morality and capacity of the village apparatus. In addition, a leader must provide real examples of good behavior and not deviate, so that the subordinates will imitate him. Leaders who have good morality will become role models and direct their subordinates not to commit fraud.

Associated with the GONE theory, low individual morality can cause someone to commit acts of fraud. The lower the level of individual morality owned by the village officials, the higher the greed which will cause someone to be easily tempted supported by the opportunity to commit fraud. Village officials who have a low level of individual morality will tend to violate regulations and are not afraid of the consequences and punishments that will be received if they commit acts of fraud. However, the results of this research indicate that the respondent's understanding of individual morality is that someone can be said to be "moral" when obeying boss. Therefore, although the results of this study state that village officials are at a high level of individual morality, they can still commit acts of fraud because they have a different understanding of morality. The role of the leader is very important. If the leader of the institution has high individual morality, it will be used as an example for his subordinates and can bring the institution to be trustworthy in carrying out the functions which will prevent fraud in the institution.

\section{B. The Effect of Information Asymmetry on the Tendency of Accounting Fraud}

The results of testing the information asymmetry variable in this research are in accordance with the research of Ahriati et al. [13] which states that there was no effect of information asymmetry on the tendency of accounting fraud. That is, the condition of information asymmetry in the scope of the Village Government of Kesamben District was not found because there was no information gap between the Village Government and the head of district because the answers given by respondents tended to agree and understand all information related to the accounting process, preparation of financial reports, and financial reporting. According to researchers, because the disclosure of information is good enough because the supervision and inspection by internal auditors has been running and carried out regularly. Audit findings obtained by internal auditors can be used as a tool in an effort to minimize the occurrence of information asymmetry. With the confirmation of audit findings by the internal auditor to both parties, it is hoped that it will create an open situation so that transparency can be further enhanced. With the disclosure of 
information, it will become a means of public supervision of the performance of the Village Government which will create a government that is clean, efficient, and free from accounting fraud. Information disclosure and information delivery activities in Kemirigede Village on financial statements have been carried out quite well which are stated as follows:

"If we say good, it's actually not perfect, because in my opinion there are still many things that need to be improved. I think the information disclosure is already open, but maybe from other parties it is still lacking "

Monitoring and inspection by internal auditors is also very important because it is done regularly. The internal auditors who are in charge of monitoring and checking are village assistants, Village Consultative Body, Government Internal Supervisory Apparatus, and the Village Community Empowerment Service. Apart from supervision and inspection carried out by the internal auditors, there are other measures taken to prevent information asymmetry by the Village Head of Kemirigede, that is involving the community in preparing the financial budgeting and preparing financial reports. This is shown by the following interviews:

"In relation to the preparation of financial reports, we usually hold hamlet meetings and village deliberations. Then we discuss the village budget. So we all involve the community in the preparation of financial reports process.

For finance with the existing development we are transparent and we will net the public aspirations."

If the results of this research are linked to the GONE theory, every individual in the institution will have the opportunity to commit fraud. The opening of opportunities for fraud occurs because in the institution there has been information asymmetry. The differences in information can be an opportunity for someone to commit fraud. However, this can be prevented if the role of the internal auditor is running properly so that it will create information transparency between the Village Government and the Sub-district Head.

\section{The Effect of Effectiveness of Internal Control on the Tendency of Accounting Fraud}

In the variable of internal control effectiveness, there are invalid indicators, namely indicators of the accounting information system used in agencies. This invalid result may be caused by not all human resources owned by the Village Government that can accept a technological novelty. According to researchers, the ability of respondents to learn and operate a new system is also influenced by the level of education they have. It may be that respondents who have a higher education level can easily accept a new system or application, but for respondents who have an Elementary School / Junior High School education level it will be quite difficult to learn and operate a system in a short time.

The results of this research are in accordance with the research of Ahriati et al. [13] which states that there is no influence of the internal control system on the tendency of accounting fraud. The results of data analysis show that the effectiveness of internal control has no effect on the tendency of accounting fraud in the village government. This condition can be caused because effective internal control has been successfully implemented in villages in Kesamben District. This is in accordance with the results of an interview with $\mathrm{Mr}$. Hari Purnawan who stated that in Kemirigede the division of tasks, responsibilities and authorities had been clearly regulated by village officials. So far in Kemirigede, there has never been a case of document falsification or proof of transactions in making financial reports. Physical checks are carried out for documents related to transactions and assets owned by Kemirigede and have been carried out periodically by the inspectorate as of the internal supervisor. This inspection is expected to help the Village Government to make effective internal controls. In Kemirigede, the Sikeudes (Village Financial System) application is used to carry out financial administration activities. The system used has also been integrated with those in charge of overseeing the performance of agencies, namely the Indonesian Financial Supervisory Agency and the Corruption Eradication Commission so that transparency can be said to be quite good. This is shown by the interview conducted with the Village Head of Kemirigede as follows:

"The application used is Sikeudes (Village Financial System). This system greatly facilitates the recording of transactions up to making financial reports. So if Sikeudes can be directly accessed at the Indonesian Financial Supervisory Agency and Corruption Eradication Commission can go directly to the so everything is connected. So transparency can be said to be good enough. With the SisKeuDes, there is no such term as "Use of funds at will."

In addition to the audits carried out by the Indonesian Financial Supervisory Agency and the Corruption Eradication Commission through the accounting system used, direct examinations are also carried out by the Government Internal Supervisory Apparatus and the Community Empowerment Service by examining financial files and reports. Internal inspection and monitoring is carried out once a year. Financial services and management at the Kemirigede have been carried out transparently. The village head of Kemirigede was very strict in providing directions regarding this matter. Illegal levies or other illegal charges on the community have also been avoided. Because the village head of Kemirigede thought that in addition to being detrimental to the village community, it could also cause the agency to deal with the authorities.

Internal control in Kemirigede can be declared quite effective because it uses an accounting information system, namely the Village Financial System which is directly integrated with the Indonesian Financial Supervisory Agency and Corruption Eradication Commission so that the use of funds cannot be done arbitrarily. In addition, the creative thinking of the village head of Kemirigede can be used as an example by other villages in Kesamben District. Associated with the GONE theory, the effectiveness of internal control can 
prevent village officials from committing fraud because there are no opportunities. A good and effective internal control system will assist the work of village officials in presenting financial reports accurately and with confidence, making or taking the right decisions, safeguarding village assets, avoiding fraud, and complying with applicable laws and regulations.

\section{The Effect of Conformity of Compensation on the Tendency of Accounting Fraud}

Statistical analysis showed that the suitability of compensation didn't have effect on the tendency of accounting fraud in the village government. This indicates that the suitability of compensation received by village officials in the villages of Kesamben District didn't have affect behavior in committing accounting fraud. The results of this research were in accordance with the research of Ahriati et al. [13] which states that there was no effect of the suitability of compensation on the tendency of accounting fraud. According to researchers, this can be due to the compensation received by all the instruments is evenly distributed and in accordance with their respective duties. But basically humans have an instinct to be dissatisfied and always feel less with what they have got. And every individual has different needs and wants. This instinct and diversity causes a person to not care about how to get compensation. Even though the method used to get compensation is the wrong way, many individuals still do it in order to fulfill all their needs and wants. So all actions taken by a person depend on the individual morality concerned.

In Kemirigede, village officials often delay to receive compensation. This is due to the delay in transfers from the central or regional governments to the village government. This is in accordance with the results of the interview submitted by Mr. Hari Purnawan as follows:

"Late payments are common. So from the beginning of this year until now we have never received a salary. Usually in April, Insya Allah, it will be realized. "

As long as they have not received a salary, the Village Government of Kemirigede manages the village land fund which will be distributed to all village officials as an incentive or commonly called an additional income allowance to meet the needs of village officials. In addition, insurance is also provided to village officials so that they feel comfortable while working. The insurance received by village officials consists of BPJS Kesehatan and BPJS Ketenagakerjaan. This is in accordance with the results of the interview with Mr. Hari Purnawan as follows:

"So we just call it additional income allowance for village officials, the funds are taken from village land. So far, we used this funds to fulfill family economic before we received salary. For insurance, we join BPJS Health and BPJS Ketenagakerjaan. "

The condition that occurs in Kemirigede is that village officials often experience delays in receiving salaries. In addition, the incentives, insurance, and facilities provided by agencies are also very reasonable. However, even in such conditions, the Kemirigede Village Government tries to manage funds so that all needs can be met. It is hoped that the management of these funds will be able to control the attitudes and behavior of village officials so that in Kemirigede there are no cases of village officials committing accounting fraud.

Related to the GONE theory, to prevent fraud, the institution can provide appropriate compensation to village officials. But in general, humans have an insatiable nature where this is one of the conditions that will encourage someone to do everything they can to get their own benefit. Other situations that can cause someone to commit fraud are due to financial and economic deficiency that occur in their personal life. When the all needs cannot be fulfilled with the income received, there will be a tendency for someone to commit fraud to meet all their needs.

\section{CONCLUSION AND SUGGESTION}

Based on the analysis result, cultivating the individual morality of village officials can prevent accounting fraud if done properly. Activities of fostering and increasing faith, increasing self-righteousness, and instilling moral values that can be adhered to in accordance with Pancasila can be used as alternatives that must be taken. A concrete step that can be taken by the Village Government is to carry out a program of Dhuhur prayer activities in congregation at the village office. With this program, it can improve harmony between colleagues. In addition, the Dhuhur prayer program in congregation can improve an attitude of discipline and noble character (integrity), which is an exercise in character building for all village officials. The schedule of who is assigned to be the muadzin and Islamic priest must be determined in advance so that can increase the discipline attitude.

Transparency or information disclosure needs to be improved by maximizing the role of the internal auditor so that information asymmetry does not occur between the Village Government and the Head of Sub-district and involves the role of the community in managing village funds. With information disclosure, it will create a government that is trustworthy in carrying out its mandate to serve the public well and free from accounting fraud. Transparency or information disclosure can be done by publishing the village budgeting to the public either offline or online. Offline publication can be done by installing billboards about the details of village budgeting at the village office so that information can be seen by anyone visiting the village office. However, the village government can use the official website and social media (Facebook and Instagram) to publish information about village budgeting and the development of activity programs carried out by the Village Government which can be seen directly by the public. After carrying out the above activities, expected the public participation in village development will increase and public trust will increase if the village government is consistent in providing transparent and reliable financial accountability information which in turn will strengthen public support for village governance. 
An effective internal control system will assist village officials in carrying out their duties. Human resources must be improved through training in financial system applications so that all village officials are able to learn and operate the Siskeudes (Village Financial System) application. The workshop should be carried out by the Regional Government together with representatives from each village to prepare human resources to better understand the procedures for operating the Siskeudes. After implementing the Siskeudes, evaluation activities are carried out by presenting a representative operator from each village in order to convey the obstacles faced while operating the Siskeudes application. With this evaluation, activity hoped the village representative operators can overcome the obstacles faced and be better prepared in operating the Siskeudes application. With the Siskeudes application and supported by adequate human resources, it can minimize the risk of errors so that the process of presenting financial statements can be carried out accurately and decision making can be carried out appropriately.

The timeliness of receiving compensation by village officials must be of particular concern to the Central or Regional Government, given the instinct of a human being who is never satisfied and the different needs and desires of each individual. If the delay is sustainable, it will cause "reckless" action by village officials to fulfill all their needs and desires. In addition, the Village Government can manage funds for exbent land as has been done by the Village Government of Kemirigede in order to meet the needs of village officials, which can prevent village officials from committing fraud.

\section{REFERENCES}

[1] Mautz and Sharaf, The Philosophy of Auditing, American Accounting Association Monograph No. 6, Florida, USA. 1961.

[2] G.A.K.R.S. Dewi, "Pengaruh Moralitas Individu Dan Pengendalian Internal Pada Kecurangan Akuntansi (Studi Eksperimen pada Pemerintah Daerah Provinsi Bali)". Jurnal Ilmiah Akuntansi, 1(1), 7792. 2017.
[3] D. Boli, Moralitas, Peran Sebagai, Individu Pada, Pemediasi Sistem, Pengaruh Internal, Pengendalian Etis, Budaya Terhadap, Organisasi Role, T H E Individual, O F As, Morality Mediation, T H E. Universitas Hasanuddin Makassar. 2017.

[4] A.N. Fatun, Faktor-Faktor Yang Mempengaruhi Kecenderungan Kecurangan (Fraud): Persepsi Pegawai Dinas Provinsi DIY. Universitas Negeri Semarang. 2013.

[5] M.D. Setiawan, et al., "Pengaruh Sistem Pengendalian Intern, Asimetri Informasi, Dan Keadilan Organisasi Terhadap Kecurangan (Fraud) (Studi Empiris Pada Bank Perkreditan Rakyat Se-Kabupaten Buleleng)". JIMAT (Jurnal Ilmiah Mahasiswa Akuntansi S1), 3(1). 2015

[6] D.N. Sri Damayanti, "Pengaruh Pengendalian Internal Dan Moralitas Individu Terhadap Kecurangan Akuntansi”. Nominal, Barometer Riset Akuntansi Dan Manajemen, 5(2). 2016.

[7] M.S. Hasibuan, Manajemen: Dasar, Pengertian, dan Masalah. Bumi Aksara. 2009.

[8] R. Amalia, Pengaruh Asimetri Informasi, Moralitas Pimpinan, Kesesuaian Kompensasi, Efektivitas Pengendalian Internal, Good Governance, dan Keadilan Organisasi Terhadap Kecenderungan Kecurangan Akuntansi (Studi Empiris Dinas Pendapatan Pengelolaan Keuangan dan Aset D. Universitas Islam Indonesia Yogyakarta. 2018.

[9] F.Q. Nugroho, Pengaruh Moralitas Individu dan Idealisme Terhadap Persepsi Etis Mahasiswa Akuntansi Mengenai Praktik Akuntansi Kreatif di Perusahaan dengan Tingkat Pemahaman Kode Etik Akuntan Sebagai Variabel Moderasi (Studi pada Mahasiswa Prodi Akuntansi Universitas Ne. Universitas Negeri Yogyakarta. 2017.

[10] A. Arifah, Pengaruh Ketaatan Aturan Akuntansi, Keefektifan Pengendalian Internal, Kesesuaian Kompensasi, keadilan Prosedural, dan Komitmen Organisasi Terhadap Kecenderungan Kecurangan Akuntansi (Studi pada Perguruan Tinggi Negeri di Daerah Istimewa Yogyakarta). Universitas Negeri Yogyakarta. 2017.

[11] I.S. Fauzya, Pengaruh Keefektifan Sistem Pengendalian Internal, Kesesuaian Kompensasi, Moralitas Individu, Dan Asimetri Informasi Terhadap Kecenderungan Kecurangan Akuntansi Dengan Perilaku Tidak Etis Sebagai Variabel Intervening Pada Bppkad Kabupaten Sragen. 1149. 2017.

[12] G. HofstedeThe Cultural Relativity Of Organizational Practicesand Theories. 75-89. 1983.

[13] D. Ahriati, P. Basuki, \& E. Widiastuty, "Analisis Pengaruh Sistem Pengendalian Internal, Asimetri Informasi, Perilaku Tidak Etis Dan Kesesuaian Kompensasi Terhadap Kecenderungan Kecurangan Akuntansi Pada Pemerintah Daerah Kabupaten Lombok Timur”. Jurnal InFestasi, 11(1), 41-55. 2015. 